\title{
Assessment of Genetic Diversity of Rice Genotypes for Submergence Tolerance in Rainfed Lowlands
}

\author{
G. Lahari, B.M. Dushyanthakumar, G.B. Jagadeesh, G.K. Nishanth* and P. Raghavendra \\ Department of Genetics and Plant Breeding, UAHS, Shivamogga-577204, Karnataka, India \\ *Corresponding author
}

\author{
A B S T R A C T
}

\section{Keywords \\ Genetic diversity, Rice genotypes, Tolerance. \\ Article Info \\ Accepted: \\ 17 September 2017 Available Online: 10 November 2017}

The present investigation to assess genetic diversity among forty nine rice genotypes including four checks (FR13A, Hemavathi, Swarna Sub1 and Jyothi) was conducted at College of Agriculture, University of Agricultural and Horticultural Sciences (UAHS), Shivamogga during Kharif 2016. The clustering pattern based on Mahalanobis' ${ }^{2}$ analysis revealed that forty nine genotypes were grouped into eight clusters where cluster VI being the largest cluster with 10 genotypes and cluster I being the smallest (1 genotype). The maximum intra cluster distance was exhibited by cluster VII (98.11). The maximum inter cluster distance was recorded between cluster VII and cluster VIII suggesting that the genotypes constituted in these clusters can be used as parents for future hybridization programme, while the minimum was between cluster V and cluster VI (57.17). Cluster II had showed highest mean values for number of tillers per plant, number of productive tillers per plant, number of spikelets per panicle, number of filled grains per panicle, grain yield per plant, straw yield per plant. Traits like absolute growth rate, days to 50 per cent flowering, days to maturity, plant height, number of filled grains per panicle and grain yield per plant had contributed 95.24 per cent towards the total genetic divergence among the genotypes. Hence these traits should be given foremost importance while selecting parents in hybridization programme.

\section{Introduction}

Rice is regarded as the life for most of the people residing in Asia as more than 90 per cent of the rice is being produced and consumed in Asia. The alarming threat for rice production in the recent years is ever increasing population and the climatic changes caused by global warming which has led to drastic raise in temperature, melting of polar ice caps, floods, drought and salinity intrusion. The rainfed lowland rice ecosystem is one such largest rice producing environment in Asia which is unfavorably affected by flooding due to complete submergence every year. Rice production in these areas is primarily dependent on rainfall and runoff which usually experience erratic floods caused by heavy rainfall and overflow of nearby rivers and canals. Over 13 million hectares of rice area in India, 3 million hectares in Bangladesh, 5 million hectares in Indonesia and 1 million hectare in Thailand are affected annually by monsoon floods causing substantial crop losses and submergence is identified as the third most important of 42 biotic and abiotic stresses (Vergara et al., 2014). The future food supply 
will greatly depend on rainfed lowland environment. Hence improving the rice productivity under such ecosystem should be considered as a priority.

Improvement of a crop mainly depends on presence of wide genetic variability among genotypes followed by adopting suitable breeding methods. Precise information regarding nature and magnitude of genetic diversity present in the existing germplasm source helps in choice of parents for hybridization programmes and for planning the future breeding programmes.

Therefore the present study is carried out to ascertain the genetic diversity among forty nine rice genotypes under submergence condition using Mahalanobis' $\mathrm{D}^{2}$ statistic.

\section{Materials and Methods}

The experimental material consisted of forty nine rice genotypes including four checks (FR13A, Hemavathi, Swarna Sub1 and Jyothi) laid out in Randomised Complete Block design (RCBD) with two replications at College of Agriculture, University of Agricultural and Horticultural Sciences (UAHS), Shivamogga during Kharif 2016. 21 days old seedlings were transplanted with a spacing of $20 \times 10 \mathrm{~cm}$ and the water depth was maintained at $50-60 \mathrm{~cm}$ for 14 days. Excess water was drained out after 14 days of submergence.

Observations on days to 50 per cent flowering, days to maturity, plant height $(\mathrm{cm})$, absolute growth rate (mg/day/plant), panicle length $(\mathrm{cm})$, number of tillers per plant, number of productive tillers per plant, number of spikelets per panicle, number of filled grains per panicle, grain yield per plant $(\mathrm{g})$, straw yield per plant (g), harvest index (\%) and 1000 grain weight $(\mathrm{g})$ were recorded based on five randomly selected plants in each genotype. The genetic divergence among the genotypes was determined using Mahalanobis' $\mathrm{D}^{2}$ (1936) statistic and grouping of genotypes into clusters was done by using Tocher's method (Rao, 1952).

\section{Results and Discussion}

The forty nine genotypes were grouped into eight clusters (Table 1) where cluster VI being the largest cluster with 10 genotypes followed by cluster VIII with 9 genotypes, cluster III and IV with 7 genotypes each, cluster II with 6 genotypes, cluster V with 5 genotypes, cluster VII with 4 genotypes and cluster I being the solitary cluster.

Presence of a single genotype in a cluster indicates high degree of divergence from other genotypes. These results were in accordance with the research findings obtained by Chamundeswari (2016) and Venkatesan et al., (2016).

The intra and inter cluster $\mathrm{D}^{2}$ values for 49 rice genotypes were shown in Table 2. The maximum intra cluster distance was shown by cluster VII (98.11). Hence the genotypes falling into cluster VII (IET 17326, IET 18130, IET 19941, Swarna sub1) can be used in crossing programs owing to the presence of greater diversity within these genotypes.

Cluster VII (IET 17326, IET 18130, IET 19941,Swarna sub1) and cluster VIII (IET 18628, IET 16488, IET 17393, IET 19952, IET 17740, IET 18508, IET 17396, IET 15512, IET 18647) showed highest inter cluster distance (965.38) followed by cluster VI (IET 20267, IET 16209, IET 17777, IET 19159, IET 14329, IET 19924, IET 17721, IET 17718, IET 20251, IET 20358) and cluster VIII (924.36) whereas the lowest inter cluster distance was noticed between cluster $\mathrm{V}$ and cluster VI (57.17) followed by cluster III and cluster VII (57.61). 
Table.1 Clustering pattern of 49 rice genotypes based on $\mathrm{D}^{2}$ values under submergence condition

\begin{tabular}{|c|c|l|}
\hline Clusters & No. of genotypes & \multicolumn{1}{|c|}{ Cluster members } \\
\hline I & 1 & Hemavathi \\
\hline II & 6 & IET 19931, IET 19157, IET 17327, IET 19134, IET 17778, FR13A \\
\hline III & 7 & IET 17741, IET 17390, IET 19945, IET 20234, IET 19429, IET 18648, IET 20006 \\
\hline IV & 7 & IET 20069, IET 19913, IET 17724, IET 20231, IET 19133, IET 17423, Jyothi \\
\hline V & 5 & IET 17424, IET 19171, IET 18796, IET 20261, IET 17717 \\
\hline VI & 10 & $\begin{array}{l}\text { IET 20267, IET 16209, IET 17777, IET 19159, IET 14329, IET 19924, IET 17721, } \\
\text { IET 17718, IET 20251, IET 20358 }\end{array}$ \\
\hline VII & 4 & IET 17326, IET 18130, IET 19941, Swarna Sub1 \\
\hline VIII & 9 & $\begin{array}{l}\text { IET 18628, IET 16488, IET 17393, IET 19952, IET 17740, IET 18508, IET 19958, } \\
\text { IET 15512, IET 18647 }\end{array}$ \\
\hline
\end{tabular}

Table.2 Inter and intra cluster distances for yield and its component characters in rice genotypes under submergence condition

\begin{tabular}{|c|c|c|c|c|c|c|c|c|}
\hline CLUSTERS & $\mathbf{I}$ & II & III & IV & $\mathbf{V}$ & VI & VII & VIII \\
\hline I & 0.00 & 166.73 & 173.04 & 207.14 & 233.09 & 386.55 & 296.07 & 397.14 \\
\hline II & & 0.00 & 77.31 & 403.46 & 257.13 & 489.09 & 106.83 & 703.44 \\
\hline III & & & 0.00 & 266.18 & 127.35 & 332.49 & 57.61 & 732.15 \\
\hline IV & & & & 0.00 & 93.46 & 128.91 & 403.81 & 508.76 \\
\hline $\mathbf{V}$ & & & & & 0.00 & 57.17 & 189.19 & 764.08 \\
\hline VI & & & & & & 0.00 & 377.78 & 924.36 \\
\hline VII & & & & & & & 98.11 & 965.38 \\
\hline VIII & & & & & & & & 0.00 \\
\hline
\end{tabular}

* Diagonal values indicate intra cluster distances and above diagonal values indicate inter cluster distances 


\section{Int.J.Curr.Microbiol.App.Sci (2017) 6(11): 2149-2154}

Table.3 Cluster means for yield and its component characters in rice genotypes under submergence condition

\begin{tabular}{|l|l|l|l|l|l|l|l|l|l|l|l|l|l|}
\hline & $\mathbf{X}_{\mathbf{1}}$ & $\mathbf{X}_{\mathbf{2}}$ & $\mathbf{X}_{\mathbf{3}}$ & $\mathbf{X}_{\mathbf{4}}$ & $\mathbf{X}_{\mathbf{5}}$ & $\mathbf{X}_{\mathbf{6}}$ & $\mathbf{X}_{\mathbf{7}}$ & $\mathbf{X}_{\mathbf{8}}$ & $\mathbf{X}_{\mathbf{9}}$ & $\mathbf{X}_{\mathbf{1 0}}$ & $\mathbf{X}_{\mathbf{1 1}}$ & $\mathbf{X}_{\mathbf{1 2}}$ & $\mathbf{X}_{\mathbf{1 3}}$ \\
\hline Cluster I & 112.10 & 145.80 & 119.02 & 14.13 & 12.39 & 246.45 & 209.90 & 24.66 & 34.15 & 45.56 & 42.79 & 24.69 & 24.00 \\
\hline Cluster II & 129.00 & 159.00 & 121.35 & 16.00 & 14.00 & 268.00 & 254.00 & 25.04 & 49.38 & 68.00 & 42.07 & 27.60 & 21.35 \\
\hline Cluster III & 121.50 & 154.00 & 151.50 & 10.50 & 9.50 & 240.00 & 223.00 & 27.50 & 37.64 & 55.00 & 40.63 & 21.77 & 31.00 \\
\hline Cluster V & 121.50 & 153.00 & 126.28 & 10.50 & 8.50 & 228.00 & 209.00 & 26.84 & 33.60 & 46.50 & 41.93 & 21.75 & 34.60 \\
\hline Cluster VI & 118.50 & 155.50 & 115.29 & 10.50 & 8.50 & 226.00 & 201.00 & 21.97 & 27.05 & 34.56 & 44.67 & 23.24 & 40.00 \\
\hline Cluster VII & 133.00 & 164.50 & 155.50 & 13.50 & 12.50 & 256.50 & 233.00 & 24.75 & 32.69 & 46.00 & 41.55 & 28.20 & 27.00 \\
\hline ClusterVIII & 104.00 & 131.50 & 91.36 & 5.00 & 4.50 & 106.00 & 84.00 & 21.49 & 13.05 & 29.60 & 30.33 & 21.79 & 10.50 \\
\hline
\end{tabular}

Where,

$\mathrm{X}_{1}$ - Days to 50 per cent flowering

$\mathrm{X}_{2}$ - Days to maturity

$\mathrm{X}_{3}$ - Plant height $(\mathrm{cm})$

$\mathrm{X}_{4}$ - Number of tillers per plant

$\mathrm{X}_{5}$ - Number of productive tillers per plant $\mathrm{X}_{10}-$ Straw yield per plant $(\mathrm{g})$
$\mathrm{X}_{11}$ - Harvest index $(\%)$

$\mathrm{X}_{12-}-1000$ grain weight $(\mathrm{g})$

$\mathrm{X}_{13}$ - Absolute growth rate $(\mathrm{mg} / \mathrm{day} / \mathrm{plant})$
Number of spikelets per panicle

$X_{7}$ - Number of filled grains per panicle

$\mathrm{X}_{8}$ - Panicle length $(\mathrm{cm})$

- Grain yield per plant $(\mathrm{g})$ 
Table.4 Estimates of per cent contribution of each character towards divergence in rice genotypes under submergence condition

\begin{tabular}{|c|l|c|}
\hline Sl. No. & \multicolumn{1}{|c|}{ Characters } & Contribution (\%) \\
\hline 1 & Absolute growth rate (mg/day/plant) & 43.62 \\
\hline 2 & Days to 50 per cent flowering & 22.87 \\
\hline 3 & Days to maturity & 9.35 \\
\hline 4 & Plant height (cm) & 8.76 \\
\hline 5 & Number of filled grains per panicle & 4.17 \\
\hline 6 & Grain yield per plant (g) & 4.17 \\
\hline 7 & Straw yield per plant (g) & 2.30 \\
\hline 8 & Number of spikelets per panicle & 2.21 \\
\hline 9 & 1000 grain weight (g) & 0.85 \\
\hline 10 & Number of tillers per plant & 0.68 \\
\hline 11 & Harvest index (\%) & 0.60 \\
\hline 12 & Panicle length (cm) & 0.34 \\
\hline 13 & Number of productive tillers per plant & 0.09 \\
\hline
\end{tabular}

The maximum inter cluster distance indicates the wider genetic diversity among the genotypes falling into the groups which can be utilized in hybridization programs while the minimum inter cluster distance indicates that the genotypes falling in such clusters are closely related and thus hybridization among such genotypes will not give any fruitful result. The greater distance between the two clusters indicates the wider genetic diversity between the genotypes (Ahmed et al., 2015). Hence it is desirable to select genotypes from the clusters showing high inter cluster distance coupled with high grain yield as parents in future breeding programs for developing varieties and hybrids with wider variability and desirable quality for submergence tolerance.

The cluster means of thirteen characters across eight clusters under submergence condition are presented in Table 3. None of the clusters contained genotypes with all the desirable traits which could be directly selected. Cluster II (IET 19931, IET 19157,
IET 17327, IET 19134, IET 17778, FR13A) had showed highest mean values for number of tillers per plant, number of productive tillers per plant, number of spikelets per panicle, number of filled grains per panicle, grain yield per plant, straw yield per plant and cluster VII (IET 17326, IET 18130, IET 19941, Swarna sub1) had showed highest mean values for days to 50 per cent flowering, days to maturity, plant height and 1000 grain weight. The genotypes selected from these clusters with high mean values would be directly chosen as parents in future breeding programs. Similar research findings were also reported by Bose and Pradhan (2005) and Sridhar et al., (2016) while carrying out genetic diversity studies in deep water rice genotypes, wherein they emphasized the fact that hybridization between genotypes selected from different clusters is essential for their use as potential parents in hybridization programme or for the development of desirable genotypes. The maximum contribution towards divergence (Table 4) was made by absolute growth rate followed 
by days to 50 per cent flowering, days to maturity, plant height, number of filled grains per panicle, grain yield per plant which has contributed 95.24 per cent towards the total genetic divergence among the genotypes. Bose and Pradhan (2005), Banumathy et al., (2010) reported about maximum contribution of days to 50 per cent flowering, plant height and grain yield per plant towards total divergence. Hence these traits should be given foremost importance while selecting parents in hybridization programs.

The success of any plant breeding program greatly depends on the existence of diversity among the genotypes The present study on cluster analysis indicated that the crosses involving the genotypes from cluster VII (IET 17326, IET 18130, IET 19941, Swarna sub1) and VIII (IET 18628, IET 16488, IET 17393, IET 19952, IET 17740, IET 18508, IET 17396, IET 15512, IET 18647), cluster VI (IET 20267, IET 16209, IET 17777, IET 19159, IET 14329, IET 19924, IET 17721, IET 17718, IET 20251, IET 20358) and VIII which had showed maximum inter cluster distance and the traits namely absolute growth rate, days to 50 per cent flowering, days to maturity, plant height, number of filled grains per panicle and grain yield per plant which showed maximum contribution towards total divergence should be given prime importance during hybridization programmes.

Hence, these genotypes can be efficiently used in future hybridization programs to develop high yielding submergence tolerant varieties.

\section{References}

Ahmed, M. S., Parveen, S., Bashar, M. K. and Shamsuddin A. K. M., 2015, Genetic divergence of balam rice (Oryza sativa L.) germplasm of Bangladesh. Bangladesh Rice J., 19(1): 9-15.

Banumathy, S., Manimaran, R., Sheeba, A., Manivannan, N., Ramya, B., Kumar, D. and Ramasubramanian, G.V., 2010, Genetic diversity analysis of rice germplasm lines for yield attributing traits. Electron. J. Plant Breed., 1(4):500-504.

Bose, L. K. and Pradhan, S. K., 2005, Genetic divergence in deepwater rice genotypes. $J$. Cent. Eur. Agric., 6(4):635-640.

Chamundeswari, N., 2016, Studies on nature of genetic divergence in rice (Oryza sativa L.). Int. J. Sci. Environ. Technol., 5(6):4018 4023.

Mahalanobis, P. C., 1936, On the generalized distance in statistics. Proc. Nat. Inst. Sci. India, 2: 49-55.

Rao, C. R., 1952, Advance statistical methods in biometric research. John Wiley and Sons Inc., New York.

Sridhar, T. C., Dushyanthakumar, B. M., Mani, B. R., and Nishanth, G. K., 2016, Genetic diversity, variability and association analysis for yield traits in traditional rice (L.) cultivars of southern Karnataka. Green Farming, 7(4):774-778.

Venkatesan, M., Sowmiya, C. A. and Anbarasi, B., 2016, Studies on genetic diversity of rice (Oryza sativa L.) under submergence. Plant Archives, 16(2): 617-620.

Vergara, G.V., Nugraha, Y., Esguerra, M. Q., Mackill, D. J. and Ismail, A. M., 2014, Variation in tolerance of rice to long-term stagnant flooding that submerges most of the shoot will aid in breeding tolerant cultivars. Ann. Bot., 6: 1-16.

\section{How to cite this article:}

Lahari, G., B.M. Dushyanthakumar, G.B. Jagadeesh, G.K. Nishanth and Raghavendra, P. 2017. Assessment of Genetic Diversity of Rice Genotypes for Submergence Tolerance in Rainfed Lowlands. Int.J.Curr.Microbiol.App.Sci. 6(11): 2149-2154.

doi: https://doi.org/10.20546/ijcmas.2017.611.253 